Stanisław Wronka, Cztowiek jako istota relacyjna w Piśmie Świętym,

[w:] Cztowiek w relacji do... Rozważania o cztowieku jako istocie relacyjnej,

red. Grzegorz Wąchol, Kraków 2020, s. 161-192.

DOI: http://dx.doi.org./10.15633/9788374388740.10

KS. DR HAB. STANIS ŁAW WRONKA

\title{
Człowiek jako istota relacyjna w Piśmie Świętym
}

Człowiek jest koroną widzialnego świata, przewyższa wszystkie inne byty materialne. Sam jest tajemniczym światem, nie do końca poznanym. Nie rozumiemy wszystkich mechanizmów jego złożonego ciała, a tym bardziej nie jesteśmy w stanie przeniknąć jego nieogarnionego ducha. Pośród istot ziemskich tylko człowiek jest osobą.

Czym jest osoba? W naszym popularnym rozumieniu każdego dorosłego człowieka pojmujemy jako zamkniętą, samodzielną i samowystarczalną rzeczywistość, która dysponuje sama sobą. Ta zwarta egzystencja o ostro zarysowanych granicach nawiązuje kontakt $\mathrm{z}$ egzystencjami tego samego rodzaju, czyli z innymi osobami. [...]

Nie jest [osoba] tylko samowystarczalną i opartą na sobie samej rzeczywistością, lecz zawsze jest również sumą swoich relacji z innymi ludźmi i ze światem. Najsilniej widać to w miłości, w odnoszeniu się do innego „ty”, w zawierzeniu się, w ofiarowaniu. Każda osoba ludzka jest samodzielnym bytem, lecz w nadzwyczajnym wymiarze jest także „relacją” i to w sposób o wiele bardziej intensywny, niż możemy to sobie wyobrazić. Zwykle myślimy, że opieramy się sami na sobie, ale tak nie jest. Bo naprawdę nie istniejemy bez relacji, które nas tworzą. [...] 
Zróbmy teraz mały test: skreślmy z historii naszego życia wszystkich ludzi, którzy nas kiedykolwiek spotkali i z którymi kiedykolwiek mieliśmy do czynienia [...], wszystkie rzeczy, które nas kiedykolwiek zachwyciły, [...] wszystko, co kiedykolwiek spotkało nas w świecie. [...] Właściwie zupełnie nic nam nie zostaje, bo skreśliliśmy nawet naszych rodziców, którzy powołali nas do życia. Bycie osobą oznacza więc coś bardzo istotnego: funkcjonowanie w relacji. Bez splotu relacji, w którym żyliśmy w przeszłości i w którym ciągle jeszcze żyjemy, nie bylibyśmy tymi, którymi jesteśmy a nawet w ogóle by nas nie było ${ }^{1}$.

Człowiek przychodzi na świat dzięki swoim rodzicom i potrzebuje innych, żeby przeżyć, wzrastać, rozwijać się i w pełni żyć. Nie jest bytem zupełnie samowystarczalnym nawet w dorosłym życiu. Egzystuje w świecie i potrzebuje innych ludzi do normalnego życia. Potrzebuje Boga, w którym wyjaśnia się jego pochodzenie i w którym znajdzie ostateczne spełnienie. Pismo Święte przedstawia człowieka w splocie relacji z Bogiem, z drugim człowiekiem i ze światem. W artykule pragniemy skoncentrować się na tych odniesieniach, wykorzystując najpierw fundamentalne teksty z $\operatorname{Rdz} 1-3$, następnie najważniejsze przykazania miłości Boga i bliźniego, a na koniec podstawowe praktyki pobożne: modlitwę, jałmużnę i post.

\section{Relacje w stworzonym przez Boga świecie $(\operatorname{Rdz} 1-3)$}

W Rdz 1 - 3 zostały wyrażone w prostych słowach i obrazach podstawowe prawdy dotyczące Boga, człowieka i świata, relacji istniejących pomiędzy nimi. Bóg jest ukazany w tych rozdziałach jako Stwórca, Prawodawca i Sędzia. W dwóch opisach stworzenia $(\operatorname{Rdz} 1$ - 2) jawi się jako Stwórca uporządkowanego kosmosu,

1 G. Lohfink, 50 listów o wierze. Jak dzisiaj być chrześcijaninem, tłum. E. Pieciul-Karmińska, Kielce 2019, s. 136-138. 
wszystkiego, co istnieje w takim bogactwie, różnorodności i pięknie. Bóg jest jednocześnie Twórcą praw zakodowanych w świecie jako całości i w poszczególnych bytach oraz wyrażonych przy pomocy symbolu drzewa poznania dobra i zła, którego owoców nie wolno spożywać ( $\mathrm{Rdz} 2$, 9. 16-17). Przekraczanie tych praw wiąże się z poważnymi konsekwencjami. Bóg wyznacza każdemu stworzeniu własne miejsce w świecie, określa jego relacje z innymi bytami. On osądza także postępowanie człowieka i w przypadku naruszenia ustanowionego przez siebie porządku wymierza odpowiednie sankcje ( $\operatorname{Rdz} 3,8-24)$.

\section{I.I. RELACJA Z BOGIEM}

Człowiek jest zatem stworzeniem Boga, ale stworzeniem szczególnym. W pierwszym opisie stworzenia $(\operatorname{Rdz} 1,1-2,4 a)$ pojawia się na końcu wszystkich bytów jako zwieńczenie całego dzieła. Bóg powołuje człowieka (אָדָ ’adam) ${ }^{2}$ do istnienia po dłuższym namyśle

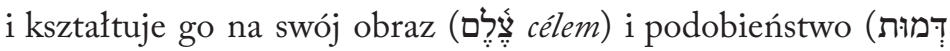
$d^{\text {e } m u t)}$ ( $\left.\operatorname{Rdz} 1,26-27\right)$. Tylko człowiek jest obrazem Boga, żadne inne stworzenie nie posiada takiej cechy. Oznacza to szczególne podobieństwo do Boga i bliskość, wyjątkową relację z Nim. Bóg czyni człowieka swoim partnerem i reprezentantem w świecie, który zostaje mu poddany ( $\mathrm{Rdz} 1,26.28)$. Według drugiego opisu stworzenia ( $R d z$ 2, 4b-25) Bóg stwarza człowieka (אָדָ 'adam) na początku ( $\mathrm{Rdz} 3,7)$, aby doglądał stworzonego później ogrodu Eden i zwierząt ( $\operatorname{Rdz} 3,15.19-20)$. Człowiek jest znów reprezentantem Boga i okazuje się zdolny do dialogu z Nim ( $\operatorname{Rdz} 2,16$; 3, 9-19).

2 Transkrypcja fonetyczna słów hebrajskich za: S. Wronka, Transliteracja i transkrypcja alfabetu hebrajskiego, „Ruch Biblijny i Liturgiczny” 57 (2004) nr 1 , s. $45-58$. 
Jest zatem człowiek stworzeniem Boga, Jego partnerem i reprezentantem, powołanym do dialogu z Nim. Winien więc odnosić się do Boga z wdzięcznością, szacunkiem i zaufaniem, podejmować mądrze i odpowiedzialnie powierzone mu zadanie, przestrzegać ustanowionych przez Niego praw. Szybko jednak człowiek zepsuł tę bliską relację z Bogiem. Okazał się nieposłuszny, pragnąc sam decydować o dobru i złu, a gdy uświadomił sobie swój czyn, zaczął lękać się Boga i stronić od Niego. W ten sposób sprowadził na siebie ograniczenia i trudności, został wydalony z ogrodu Eden, utracił bliskość z Bogiem i dostęp do drzewa życia. Jednak Bóg nie opuścił go całkowicie. Zatroszczył się o odzienie dla niego i zapowiedział Potomka niewiasty, który zwycięży Szatana symbolizowanego przez węża, sprawcę całego nieszczęścia (Rdz 3,1-24). Cała dalsza historia biblijna: dzieje Izraela, narodu wybranego, zwieńczone przyjściem Syna Bożego w Jezusie Chrystusie - jest realizacją tej protoewangelii $(\mathrm{Rdz} 3,15)$, pierwszej dobrej nowiny o przywróceniu człowieka do przyjaźni z Bogiem³.

\section{I.2. RELACJA Z DRUGIM CZŁOWIEKIEM}

W Rdz 1 - 3 opisane zostały także relacje międzyludzkie, skupione na pierwszej parze mężczyzny i kobiety, bo relacje między nimi są najbardziej wszechstronne i bogate. Pierwszy opis stworzenia stwierdza krótko, że Bóg stworzył człowieka (אָָָָ 'adam)

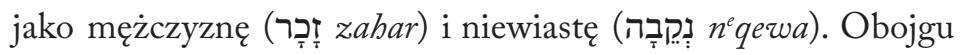
błogosławił, aby byli płodni, zaludnili ziemię, uczynili ją sobie

3 Por. M. Wojciechowski, Pochodzenie świata, cztowieka, zta. Odpowiedź Biblii, Częstochowa 2005, s. 30-33, 37-45; Ksiega Rodzaju, cz. 1, Rozdziaty 1-11, wstęp, tłum. z oryginału, komentarz oprac. J. Lemański, Częstochowa 2013, s. 165-174, 182-186, 212-237 (Nowy Komentarz Biblijny. Stary Testament, 1.1). 
poddaną i panowali nad zwierzętami ( $\operatorname{Rdz} 1,27-28)$. Nie widać tutaj żadnego zróżnicowania pomiędzy mężczyzną i kobietą co do godności i znaczenia. Mają wspólnie podejmować dzieło prokreacji i opanowywania świata, co zakłada ich ścisłą współpracę, wzajemne wsparcie i miłość.

W drugim opisie Bóg najpierw stwierdza: „Nie jest dobrze, żeby mężczyzna (אָָָָ 'adam) był sam; uczynię mu zatem odpowiednią

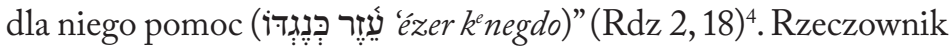
כְְִּ néged oznacza „to, co jest przeciwległe, to, co odpowiada”, a zło-

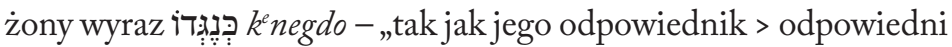
dla niego" ". Stwierdzenie to wyraża potrzebę człowieka, żeby żyć w relacji z drugim człowiekiem, samotność jest dla niego nie do zniesienia. Wśród utworzonych zwierząt nie znajduje on jednak odpowiedniej pomocy dla siebie ( $\operatorname{Rdz} 2,20)$. Dlatego Bóg z jego

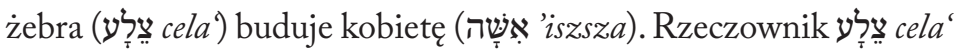
oznacza tutaj „żebro”, choć może również oznaczać „bok”, ale zwykle w odniesieniu do budowli i przedmiotów ${ }^{7}$. Obraz ten wyraża ideę równości, identyczności, co wprost potwierdza mężczyzna:

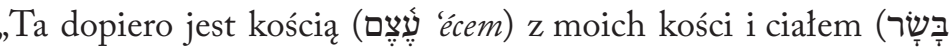

4 Polskie cytaty biblijne za: Pismo Święte Starego i Norwego Testamentu w przektadzie z jezyków oryginalnych [Biblia Tysiąclecia], oprac. zespół biblistów polskich $z$ inicjatywy benedyktynów tynieckich, Poznań 2002.

5 L. Koehler, W. Baumgartner, J. J. Stamm, Wielki stownik hebrajsko-polski i aramejsko-polski Starego Testamentu, t. 1, red. nauk. wyd. pol. P. Dec, tłum. K. Madaj i in., Warszawa 2008, s. 627 (Prymasowska Seria Biblijna, 30).

6 L. Koehler, W. Baumgartner, J. J. Stamm, Wielki stownik hebrajsko-polski i aramejsko-polski Starego Testamentu, t. 1, dz. cyt., s. 627.

7 Por. L. Koehler, W. Baumgartner, J. J. Stamm, Wielki stownik hebrajsko-polski i aramejsko-polski Starego Testamentu, t. 2, red. nauk. wyd. pol. P. Dec, tłum. K. Madaj i in., Warszawa 2008, s. 105-106 (Prymasowska Seria Biblijna, 30). 
basar) z mego ciała! Ta będzie się zwała niewiastą (אִ 'iszsza), bo ta z mężczyzny (אִ 'isz) została wzięta” ( $\operatorname{Rdz} 2,23)$. Po raz pierwszy na oznaczenie mężczyzny pojawia się tutaj rzeczownik אִיש 'isz wskazujący na poziomie terminologicznym na identyczność natury kobiety i mężczyzny; oboje są człowiekiem (אָָָ 'adam)

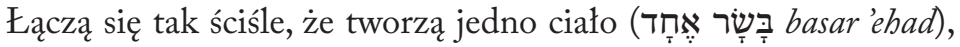
czyli doskonałą jedność psychofizyczną. Jest to obraz głębokiej, jedynej relacji, jaka łączy mężczyznę i kobietę. O jej niezakłóconym charakterze świadczy brak odczucia wstydu, mimo że oboje byli $\operatorname{nadzy}(\operatorname{Rdz} 2,24-25)$.

Ta relacja zostaje zamącona przez grzech, ukazany symbolicznie przez skosztowanie owocu $z$ drzewa poznania dobra i zła ( $R d z$ 3,1-6). Sam fakt, że kobieta pierwsza sięga po owoc, świadczy o jej autonomii, ponieważ nie działa za przykładem czy pozwoleniem mężczyzny, ale samodzielnie. Gdyby mężczyzna pierwszy zjadł owoc, kobieta musiałaby zrobić to samo w imię posłuszeństwa, do którego była zobligowana zgodnie z ówczesnym statusem kobiety. Natomiast mężczyzna nie musiał słuchać kobiety, więc podjął decyzję również samodzielnie, mimo że uczynił to po kobiecie. Teraz jednak oboje próbują zrzucić z siebie odpowiedzialność, co objawia jakieś pęknięcie w nich i między nimi. Mężczyzna wskazuje na kobietę jako przyczynę upadku, kobieta na węża ( $R d z$ 3,12-13). Konsekwencją przekroczenia Bożego przykazania jest dla obojga śmierć ( $\operatorname{Rdz} 3,19)$, a dla kobiety trud

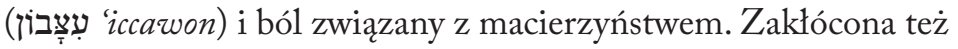

8 Polskie przekłady renesansowe Biblii próbowały oddać grę słów hebrajskich; por. Biblia w przektadzie księdza Jakuba Wujka z 1599 r., transkrypcja typu „B” oryginalnego tekstu z XVI wieku i wstępy J. Frankowski, Warszawa 1999 (Prymasowska Seria Biblijna, 10) - „mąż” i „mężyna”; Biblia Święta, to jest Księgi Starego i Nowego Przymierza z żydowskiego i greckiego jezzyka na polski pilnie i wiernie przettumaczone [Biblia gdańska], Gdańsk 1632 - „mąż” i „mężatka”. 
zostaje jej relacja z mężczyzną: „[...] ku twemu mężowi będziesz

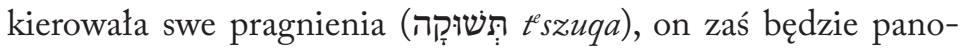
wał (משל msz) nad tobą" (Rdz 3, 16). Rzuqu oznacza „pragnienie, tęsknotę”, które kobieta będzie kierować ku mężczyźnie (por. Pnp 4,17) ${ }^{9}$, ale z jego strony spotka ją postawa panowania. Rzeczownik ten jest odniesiony także do grzechu, który kieruje swe pragnienie ku człowiekowi i jak zwierzę czyha na niego, a człowiek ma nad nim panować (משל mszl) ( $\mathrm{Rdz} 4,7)$. W świetle tego tekstu kobieta mogłaby się jawić jako siła zagrażająca mężczyźnie, starająca się go usidlić. Ale raczej w $\mathrm{Rdz}$ 3, 16 chodzi o to, że mężczyzna zagraża kobiecie, panuje nad nią, a nie traktuje jak partnera i współpracownika. Jest to nowe zachowanie, nieobecne w opisach stworzenia, niezgodne z zamysłem Stwórcy. Dalsze działania Boga opisane w Starym i Nowym Testamencie będą zmierzać do tego, by odbudować prawidłowe relacje międzyludzkie, tworzyć wspólnotę, bez której człowiek nie może dobrze funkcjonować ${ }^{10}$.

\section{I.3. RELACJA ZE ŚWIATEM}

W Rdz 1 - 3 opisano również relacje człowieka ze światem. Według pierwszego opisu został on powierzony przez Boga człowiekowi. Ma go zaludniać, czynić sobie ziemię poddaną (כבש kbsz), ma panować (רדה rdh) nad wszystkimi zwierzętami, ma ze świata brać pożywienie ( $\mathrm{Rdz} 1,26.28)$. Są nim owoce roślin, ale dalej do dyspozycji człowieka będą także zwierzęta $z$ wyjątkiem ich

9 Por. L. Koehler, W. Baumgartner, J. J. Stamm, Wielki stownik hebrajsko-polski i aramejsko-polski Starego Testamentu, t. 2, dz. cyt., s. 713.

10 Por. M. Wojciechowski, Pochodzenie swiata, cztowieka, zta, dz. cyt., s. 30-33, 37-45, 47-66; Ksiega Rodzaju, cz. 1, dz. cyt., s. 165-174, 182186, 212-237, 240-263. 
krwi (Rdz 9, 3-4). Możliwość używania mięsa zwierząt na pokarm dla ludzi zostanie podtrzymana także w Nowym Testamencie (Dz 10,12-15). Dlatego nie można z Biblii wyprowadzać obowiązku diety wegetariańskiej czy wegańskiej. Użyte czasowniki są bardzo mocne. Termin כבש kbsz oznacza „podbić (ziemię, naród), zniewolić, zgwałcić (kobietę), pognębić, upokorzyć"11. Natomiast rdh oznacza „deptać w tłoczni”, jak również „rządzić z powiązanym znaczeniem ucisku"12. Człowiek ma zatem ujarzmić sobie ziemię, jej żywioły symbolizowane m.in. przez wody, ma kontrolować dzikie bestie, które są też obrazem zła duchowego $(\operatorname{Rdz} 3,1 ; \operatorname{Rdz} 4,7)$.

Drugi opis stworzenia łagodzi nieco to odniesienie człowieka do świata. Człowiek otrzymuje ogród Eden do swojej dyspozycji z wyjątkiem owoców z drzewa poznania dobra i zła; może z niego korzystać, ale posiada też wobec niego obowiązki: ma ten ogród uprawiać (עבד 'bd) i doglądać go (שמר szmr) (Rdz 2, 5.15). Pierwszy czasownik עבד 'bd oznacza „pracować, służyć (również jako niewolnik), wypełnić, czcić, uprawiać”13. Drugi שמר szmr ma bardzo bogatą gamę znaczeń: „strzec, pilnować, zachować, troszczyć się, zbawić, wykonać polecenie, poświęcić się"14. W świetle tego tekstu człowiek ma raczej służyć światu, troszczyć się o niego, strzec go. Inne ma być też podejście do zwierząt. Człowiek szuka w nich pomocy, partnera. Nadawanie nazw wskazuje, że człowiek je przewyższa, podporządkowuje sobie. Nieznalezienie wśród nich

11 Por. L. Koehler, W. Baumgartner, J. J. Stamm, Wielki stownik hebrajsko-polski i aramejsko-polski Starego Testamentu, t. 1, dz. cyt., s. 435.

12 Por. L. Koehler, W. Baumgartner, J. J. Stamm, Wielki stownik hebrajsko-polski i aramejsko-polski Starego Testamentu, t. 2, dz. cyt., s. 240-241.

13 Por. L. Koehler, W. Baumgartner, J. J. Stamm, Wielki stownik hebrajsko-polski i aramejsko-polski Starego Testamentu, t. 1, dz. cyt., s. 724-725.

14 Por. L. Koehler, W. Baumgartner, J. J. Stamm, Wielki stownik hebrajsko-polski i aramejsko-polski Starego Testamentu, t. 2, dz. cyt., s. 546-549. 
odpowiedniej pomocy jest znakiem, że nie dorównują one człowiekowi, stoją niżej od niego.

Te dwa opisy uzupełniają się i wzajemnie ograniczają. Człowiek ma panować nad światem, nad zwierzętami, ale nie może to oznaczać plądrowania dóbr ziemskich, maltretowania zwierząt. Ma prowadzić ten świat do harmonii, do współżycia i współdziałania wszystkich jego elementów, ma przyczyniać się do jego trwania i rozwoju. Powinien brać wzór ze Stwórcy, o którym mędrzec mówi: „Potęgą władasz, a sądzisz łagodnie i rządzisz nami z wielką oględnością, bo do Ciebie należy moc, gdy zechcesz” (Mdr 12, 18). Niestety przez przekroczenie Bożego przykazania relacja człowieka ze światem również została naruszona. Ziemia jest przeklęta (אִּרוּרָ 'arura), rodzi cierń i oset zamiast płodów roli. Człowiek z trudem (עִ עִָָבוֹן 'iccawon), w pocie czoła zdobywa z niej pożywienie, a w końcu do niej powróci ( $\operatorname{Rdz} 3,17-19)$.

Opis zawarty w Rdz 3 to opis etiologiczny, mający pokazać, skąd obecnie w świecie występują ból, trud, niezgoda, śmierć, dlaczego relacje człowieka $z$ Bogiem, drugą osobą i światem są osłabione czy zniszczone. Jak widać to z dwóch opisów stworzenia, zamysł Boga był inny. Bóg stworzył uporządkowane uniwersum, w którym panowały dobre relacje, każde stworzenie miało swoje miejsce, ale człowiek ten zamysł zmącił. Zepsucie relacji z Bogiem poprzez przekroczenie Jego przykazania, wejście w Jego kompetencje odbiło się negatywnie na relacji człowieka do drugiego człowieka i do świata. Dobra relacja z Bogiem jest bazą dla innych relacji człowieka. Bóg nie zrezygnował jednak z człowieka i świata, ale próbuje te nadszarpnięte, zepsute relacje uzdrowić, naprawić. Dalsza historia biblijna jest tego świadectwem ${ }^{15}$.

15 Por. M. Wojciechowski, Pochodzenie świata, cztowieka, zta, dz. cyt., s. 30-33, 37-45, 47-66; Ksiega Rodzaju, cz. 1, dz. cyt., s. 165-174, 182186, 212-237, 240-263. 


\section{Relacje miłości z Bogiem, człowiekiem i światem}

Najpełniejszą formą relacji jest miłość, stąd częste nawoływania do niej zarówno w Starym, jak i Nowym Testamencie. Są to wezwania do miłości wobec Boga, drugiego człowieka i świata, choć te ostatnie są rzadsze i mniej wyraźne. W odniesieniu do Boga i bliźniego wezwania te przybrały postać przykazań, a więc są ważne i zobowiązują człowieka do uczenia się takich postaw. Pan Jezus wskazał przykazania miłości Boga jako najważniejsze, streszczające wszystkie inne (Mt 22, 36-40; Mk 12, 28-33). Na czym ta miłość polega, w czym się ma wyrażać?

\section{I. MIŁOŚĆ DO BOGA}

Przykazanie miłości Boga jest zawarte w tekście Pwt 6, 4-9, któ-

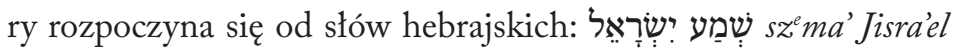
i stanowi codzienną modlitwę Izraelitów.

${ }^{4}$ Słuchaj, Izraelu, Pan jest naszym Bogiem - Pan jedynie.

${ }^{5}$ Będziesz więc miłował (אהב'bb) Pana, Boga twojego,

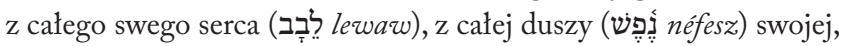

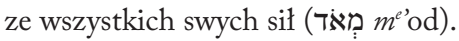

${ }^{6}$ Pozostaną w twym sercu te słowa, które ja ci dziś nakazuję.

${ }^{7}$ Wpoisz je twoim synom, będziesz o nich mówił, przebywając w domu, w czasie podróży, kładąc się spać i wstając ze snu.

${ }^{8}$ Przywiążesz je do twojej ręki jako znak. One ci będą ozdobą między oczami.

${ }^{9}$ Wypisz je na odrzwiach swojego domu i na twoich bramach.

Dla wyrażenia miłości użyty tutaj został czasownik אהב 'bb, który oznacza „kochać, lubić, cenić” i ma bardzo szerokie zastosowanie. Może oddawać miłość Bożą i ludzką, piękną i nieczystą. Podmiotem tego czasownika może być zarówno Bóg, jak i człowiek, a przedmiotem podobnie Bóg i człowiek, ale również jakaś wartość 
(mądrość, sprawiedliwość, dobro) lub rzecz (bogactwo, ciasto). Termin ten określa relację między Bogiem i człowiekiem, rodzicami i dziećmi, między małżonkami, przyjaciółmi, panem i niewolnikiem, między człowiekiem i wartością lub rzeczą. Miłość wyrażona za pomocą tego czasownika zawiera w sobie szereg aspektów, jak upodobanie, uczucie, przywiązanie, wierność, służbę, posłuszeństwo ${ }^{16}$.

Septuaginta oddała czasownik hebrajski za pomocą ả $\gamma \alpha \pi \alpha ́ \omega$, który również ma szerokie znaczenie, szersze niż pozostałe czasow-

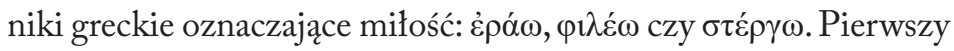
z nich odnosi się przede wszystkim do sfery erotycznej, drugi dotyczy przyjaźni, a trzeci wyraża relacje rodzinne. A $\gamma \alpha \pi \alpha ́ \omega$ nie ogranicza się do sfery uczuć czy erotyki, nie obejmuje tylko najbliższych krewnych i wyraża bardziej subtelne i aktywne odniesienie do innych ${ }^{17}$. Uwzględnienie kontekstu bliższego i dalszego pozwoli nam doprecyzować znaczenie czasownika hebrajskiego.

Miłość do Boga, którą Pwt 6, 5 nakazuje Izraelowi, powinna być „z całego serca, z całej duszy i z całej siły”. W tekście hebrajskim ostatni rzeczownik również występuje w liczbie pojedynczej, która może mieć znaczenie kolektywne „siły”. Rzeczownik „serce” (לָָב lewaw lub לִ lew) w sensie metaforycznym nie oznacza przede

16 Por. S. Wronka, Największe przykazania mitości Boga i bliźniego, w: Na Trooje stowo, Panie..., red. D. Czaicki, Kraków 2018, s. 77; L. Koehler, W. Baumgartner, J. J. Stamm, Wielki stownik hebrajsko-polski i aramejsko-polski Starego Testamentu, t. 1, dz. cyt., s. 18; S. Hałas, Biblijne stownictwo mitości i mitosierdzia na zderzeniu kultur. Określenia hebrajskie i ich odpowiedniki greckie, Kraków 2011, s. 41-50 (Studia - Uniwersytet Papieski Jana Pawła II w Krakowie. Wydział Teologiczny, 18); Księga Powtórzonego Prawa, wstęp, tłum. z oryginału, komentarz, ekskursy oprac. S. Łach, Poznań-Warszawa 1971, s. 144 (Pismo Święte Starego Testamentu, 2.3).

17 Por. S. Wronka, Największe przykazania mitości Boga i bliźniego, dz. cyt., s. 77; W. Barclay, Ważniejsze stowa Nowego Testamentu, tłum. P. Kuciński, Warszawa 1988, s. 5-11; S. Hałas, Biblijne stownictwo mitości i mitosierdzia na zderzeniu kultur, dz. cyt., s. 57-82. 
wszystkim centrum uczuć, lecz wnętrze, istotę człowieka, jego rozum, wolę i sumienie. Drugi rzeczownik „gardło, szyja, oddech, życie”, a dopiero później „istota żyjąca, człowiek, dusza”. W końcu „siła, moc” (מְאד med) oznacza siły fizyczne i psychiczne człowieka, wszystkie jego możliwości, całą aktywność, a także dobra materialne ${ }^{18}$. Septuaginta oddaje te trzy rzeczowniki

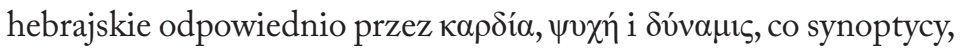
cytując Pwt 6,5, nieco modyfikują. Dodają jeszcze rzeczownik

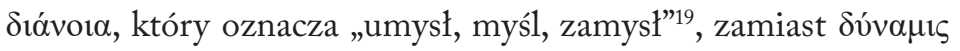
używają synonimu i $\sigma \chi u ́ s$, który bardziej akcentuje tężyznę fizycz-

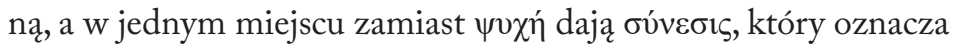
„zdolność pojmowania, umysł, rozum, inteligencję, rozumienie”20,

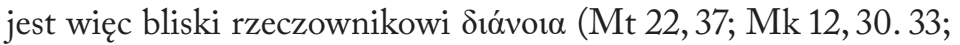
Łk 10,27). Rzeczowniki greckie odpowiadają co do sensu rze-

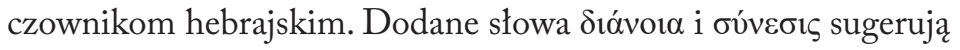
mentalność zbliżoną do greckiej, w której umysł odgrywa większą rolę. Dla Greków „serce” nie jest organem myślenia, lecz siedliskiem uczuć i namiętności. Natomiast w języku hebrajskim brak

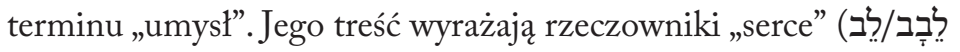

18 Por. S. Wronka, Największe przykazania mitości Boga i bliźniego, dz. cyt., s. 77-78; L. Koehler, W. Baumgartner, J. J. Stamm, Wielki stownik bebrajsko-polski i aramejsko-polski Starego Testamentu, t. 1, dz. cyt., s. 483485, 506, 668-670; S. Hałas, Biblijne stownictwo mitości i mitosierdzia na zderzeniu kultur, dz. cyt., s. 50-51, 249, 273-279; Księga Powtórzonego Prawa, dz. cyt., s. 143-144; Ewangelia wedtug św. Marka, wstęp, tłum. z oryginału, komentarz oprac. H. Langkammer, Poznań-Warszawa 1977, s. 283 (Pismo Święte Nowego Testamentu w 12 Tomach, 3.2).

19 Por. R. Popowski, Wielki stownik grecko-polski Nowego Testamentu. Wydanie z petnq lokalizacja greckich haset, kluczem polsko-greckim oraz indeksem form czasownikowych, wyd. 2, Warszawa 1995, s. 130 (Prymasowska Seria Biblijna, 3).

20 Por. R. Popowski, Wielki stownik grecko-polski Nowego Testamentu, dz. cyt., s. 584 . 


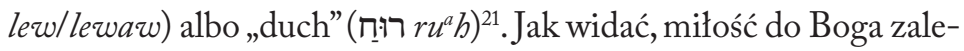
cana w Pwt 6, 5 nie polega na samym uczuciu, ale obejmuje całego człowieka, angażuje jego myślenie, sumienie, wolę, działanie, każdy oddech i całe życie, wszystkie dobra. Miłość ta oznacza rozumną, całożyciową postawę nakierowaną na Boga, z tego też powodu może być nakazana i wypracowana przez człowieka. Tak również to przykazanie jest rozumiane przez synoptyków, którzy je cytują 22 .

Z kontekstu Pwt 6, 4-9 można wywnioskować, że miłość do Boga polega przede wszystkim na słuchaniu słów, które Bóg przekazał Izraelowi. Słowa te powinny pozostać w sercu człowieka, należy je powtarzać dzieciom i mówić o nich w domu i w drodze, kładąc się spać i wstając ze snu (w. 1 i 6-7). Co więcej, mają być one przywiązane na ręce i na czole oraz wypisane na odrzwiach domu i bramy (w. 8-9). Chodzi o filakterie i mezuzy, które zawierają teksty Pięcioksięgu: Wj 13, 3-16 i Pwt 6, 4-9; 11, 13-21. Pierwszy z nich mówi o wyjściu Izraelitów z Egiptu oraz o upamiętnianiu tego wydarzenia przez obchodzenie Paschy i ofiarowanie Bogu pierworodnych potomków płci męskiej spośród ludzi i zwierząt ${ }^{23}$.

21 Por. Stownik grecko-polski, red. Z. Abramowiczówna, t. 2, Warszawa 1960, s. 560; J. Lust et al., A Greek-English Lexicon of the Septuagint, Vol. 1, Sttuttgart 1992, s. 106.

22 Por. S. Wronka, Najwięssze przykazania mitości Boga i bliźniego, dz. cyt., s. 78; Ewangelia wedtug św. Mateusza, cz. 2, Rodziaty 14-28, wstęp, tłum. z oryginału, komentarz oprac. A. Paciorek, Częstochowa 2008, s. 375 (Nowy Komentarz Biblijny. Nowy Testament, 1.2); Ewangelia wedtug śr. Marka, dz. cyt., s. 283; Erwangelia wedtug śrw. Eukasza, cz. 1, Rozdziaty 1-11, wstęp, tłum. z oryginału, komentarz oprac. F. Mickiewicz, Częstochowa 2011, s. 561 (Nowy Komentarz Biblijny. Nowy Testament, 3.1); S. Hałas, Biblijne stownictwo mitości i mitosierdzia na zderzeniu kultur, dz. cyt., s. 255-257, 259, 261.

23 Por. Ksiega Kaptańska, wstęp, tłum. z oryginału, komentarz oprac. A. Tronina, Częstochowa 2006, s. 288-289 (Nowy Komentarz Biblijny. Stary Testament, 3). 
Teksty z Pwt nakazują wypełniać polecenia Pana. Filakterie i mezuzy pomagały Izraelitom zachowywać słowa Boga ciągle przed oczyma i w pamięci, aby je wypełniać i nimi się kierować w życiu prywatnym i publicznym ${ }^{24}$.

Szerszy kontekst Pwt 4-11 zawiera słowa Boże mówiące z jednej strony o miłości i wybraniu Izraela przez Boga, wyzwoleniu go z niewoli egipskiej i obietnicy wejścia do Ziemi Obiecanej, a $z$ drugiej strony o normach postępowania, w pierwszym rzędzie zawartych w Dekalogu (Pwt 5, 6-22). Izraelici są wzywani do przestrzegania tych norm z miłości i szacunku do swego Boga. W tym okaże się ich mądrość, która zagwarantuje im pomyślność, przejęcie kraju Kanaan i przebywanie w nim w pokoju. Miłość do Boga nie może jednak polegać na niewolniczym wypełnianiu Jego przykazań, ale ma wyrazić się w wybraniu Go jako jedynego Pana, przylgnięciu do Niego, zawierzeniu Mu we wszystkim i służeniu z całym oddaniem Jemu, a nie obcym bogom. Trzeba pamiętać, że relacja pan-sługa nie wyczerpuje układu między Bogiem i Jego ludem. W innych tekstach Starego Testamentu Bóg jest dla Izraela Ojcem (Pwt 32, 6; Jr 31, 9), Oblubieńcem (Iz 54, 5; Oz 2, 4. 18), a nawet jest porównany do matki pochylającej się nad dzieckiem (Iz 49, 15; 66, 13). Obrazy te sugerują uczuciową bliskość, zażyłą relację pełną zaufania i oddania. Miłość do Boga powinna się wyrażać w takich postawach jako odpowiedź narodu i każdego Izraelity na inicjatywę Boga, który się im objawił, wybrał ich i prowadzi ich w historii, aby wypełnić swoje zbawcze plany wobec swego ludu

24 Por. S. Wronka, Największe przykazania mitości Boga i bliźniego, dz. cyt., s. 78-79; Encyklopedia biblijna, red. P. J. Achtemeier, tłum. G. Berny i in., Warszawa 1999, s. 299, 751-752 (Prymasowska Seria Biblijna, 9); F. Rienecker, G. Maier, Leksykon biblijny, tłum. D. Irmińska,J. Kruczyńska, Warszawa 2001, s. 235 (Prymasowska Seria Biblijna, 18); P. Bovati, Księga Powtórzonego Prawa (1-11), red. nauk. T. M. Dąbek, tłum. L. Furman, Kraków 1998, s. 90-92 (Rozumieć Stary Testament. Komentarze Duchowe). 
i wszystkich narodów ziemi. Jezus potwierdzi i przybliży jeszcze bardziej pełne miłości oblicze Boga oraz zachęci i ośmieli ludzi do zażyłej relacji z $\mathrm{Nim}^{25}$.

\subsection{MIŁOŚĆ DO BLIŹNIEGO}

Przykazanie miłości bliźniego przytacza Kpł 19, 18: „[...] będziesz miłował swego ${ }^{26}$ bliźniego jak siebie samego". Również tutaj wykorzystano czasownik אהב 'ל posiadający szerokie znaczenie, dlatego jego konkretną treść trzeba znowu wydobyć z kontekstu (Kpł 19). Rozdział ten wzywa do świętości: „Bądźcie świętymi, bo Ja jestem święty, Pan, Bóg wasz!” (19,2), którą wyznaczają Dekalog i inne polecenia Boże, a zwieńcza miłość. Autor przypomina szereg przykazań odnoszących się do Boga: nie czcić bożków i nie czynić ich podobizn, świętować szabat, składać należyte ofiary i szanować przybytek, nie jeść niczego z krwią i nie uprawiać wróżbiarstwa (19,3-8. 26-31). Jeszcze szerzej wymienione są przykazania odnoszące się do drugiego człowieka: szanować matkę i ojca, zostawiać resztki plonów i owoców ubogiemu i przybyszowi, nie wykorzystywać seksualnie niewolnicy ani nie czynić córki nierządnicą (sakralną), szanować starca, nie uciskać przybysza, ale go miłować, nie popełniać niesprawiedliwości w wyrokach i handlu (19,3.9-10.20-22.29.32-36). Główny blok tych nakazów znajduje się w 19, 11-18, a kończy go właśnie przykazanie miłości bliźniego: nie kraść, nie kłamać, nie oszukiwać, nie przysięgać fałszywie, nie

25 Por. S. Wronka, Największe przykazania mitości Boga i bliźniego, dz. cyt., s. 79; P. Bovati, Księga Powtórzonego Prawa (1-11), dz. cyt., s. 83-90; R. Jasnos, Teologia Prawa w Deuteronomium, Kraków 2001, s. 235-293 (Studia Pedagogiczne); S. Hałas, Biblijne stownictwo mitości i mitosierdzia na zderzeniu kultur, dz. cyt., s. 50-53, 248-252.

26 Biblia Tysiąclecia $\mathrm{z}$ niezrozumiałych względów pomija zaimek dzierżawczy „swego”. 
uciskać i nie wyzyskiwać bliźniego, nie zwlekać z zapłatą do rana, nie złorzeczyć głuchemu i nie kłaść przeszkody przed niewidomym, sądzić sprawiedliwie, nie szerzyć oszczerstw, nie czyhać na życie bliźniego, nie żywić w sercu nienawiści do brata, ale go upominać, by nie ponieść winy z jego powodu, nie szukać pomsty i nie żywić urazy do rodaków. Miłość bliźniego jest przeciwieństwem wymienionych negatywnych uczuć, postaw i działań, polega ona na wychodzeniu do drugiego człowieka, wczuwaniu się w jego sytuację i niesieniu mu dobra. Mieści się w niej także upomnienie tego, kto dopuszcza się zła. Jest więc postawą angażującą również całego człowieka, wszystkie jego władze ${ }^{27}$.

„Bliźni” w Kpł 19, 18 jest określony słowem רֵ $r e^{a}$ oznaczającym ogólnie osobę, z którą ktoś żyje w jakiejś relacji, a więc „przyjaciela, ulubieńca, towarzysza, sąsiada, bliźniego, rodaka"28. Termin ten występuje jeszcze dwa razy w najbliższym kontekście (Kpł 19, 13. 16). Można w nim widzieć tutaj rodaka, członka wspólnoty, jak na to wskazują inne wyrażenia pojawiające się w Kpł 19: „synowie Izraela/ ludu” (19, 2.18), „lud” (19, 16), „współplemieniec” (19, 11.15.17), ,brat” $(19,17)$. Termin może też oznaczać „przybysza”, który osiedlił się w Izraelu. Nie wolno go uciskać, ale należy go uważać za tubylca, pomagać mu i miłować jak siebie samego, pamiętając o swym losie przybysza w ziemi egipskiej $(19,10.33 .34)$. Tak dobrze nie postrzega cudzoziemca w Izraelu chyba żaden inny tekst Starego Testamentu. „Bliźni” oznacza więc w Kpł 19, 18 przede wszystkim każdego Izraelitę, niezależnie od jego statusu społecznego i religijnego,

27 Por. S. Wronka, Największe przykazania mitości Boga i bliźniego, dz. cyt., s. 79-80; Księga Kaptańska, wstęp, tłum. z oryginału, komentarz oprac. A. Tronina, dz. cyt., s. 281-283, 293-294; Księga Kaptańska, wstęp, tłum. z oryginału, komentarz, ekskursy oprac. S. Łach, Poznań-Warszawa 1970, s. 237-243 (Pismo Święte Starego Testamentu, 2.1).

28 Por. L. Koehler, W. Baumgartner, J. J. Stamm, Wielki stownik hebrajsko-polski i aramejsko-polski Starego Testamentu, t. 2, dz. cyt., s. 291-293. 
ale także obcego, który przebywa w Izraelu. To szerokie znaczenie z czasem zacieśniało się i ograniczało do pobożnych Izraelitów ${ }^{29}$.

Według Kpł 19, 18 bliźniego trzeba miłować ,jak siebie samego” (ๆּ̣ kamóha). Miłość do siebie ma być miarą miłości bliźniego. Jest to trudne wymaganie, bo o siebie człowiek troszczy się najbardziej i nikt go w tym nie zastąpi. Powinien jednak starać się podchodzić do drugiego tak, jak podchodzi do siebie: z życzliwością, troską, pomocą, pragnąc dobra i czyniąc je dla niego, a chroniąc przed złem ${ }^{30}$.

Jezus przytoczył również przykazanie miłości bliźniego i wskazał na jego wagę, łącząc je z przykazaniem miłości Boga (Mt 22, 39-40; Mk 12, 31. 33; Łk 10, 27). W Łk 10, 30-37 dołączył przypowieść o miłosiernym Samarytaninie, za której pomocą wyjaśnił, że mamy stawać się bliźnimi każdego człowieka i każdego człowieka mamy traktować jako bliźniego. Bohaterem przypowieści jest bowiem Samarytanin, obcy i wrogi dla Żyda z powodu swojej odrębności etnicznej i religijnej. Nie był w pełni członkiem ani narodu żydowskiego, ani wspólnoty wyznawców judaizmu. Dając go za przykład, Jezus przełamuje różnice etniczne i religijne i głosi jednoznacznie uniwersalizm, który przebłyskiwał zaledwie w tekstach Starego Testamentu. Bliźnim jest każdy człowiek, wobec którego nie można przejść obojętnie, jak uczynili to kapłan i lewita. Trzeba mu pomóc $\mathrm{w}$ potrzebie, przezwyciężając egoizm, lęk (poraniony człowiek

29 Por. S. Wronka, Największe przykazania mitości Boga i bliźniego, dz. cyt., s. 81; Ksiegga Kaptańska, wstęp, tłum. z oryginału, komentarz oprac. A. Tronina, dz. cyt., s. 287-288, 292; Ksiega Kaptańska, wstęp, tłum. z oryginału, komentarz, ekskursy oprac. S. Each, dz. cyt., s. 241, 243; F. Rienecker, G. Maier, Leksykon biblijny, dz. cyt., s. 93.

30 Por. S. Wronka, Największe przykazania mitości Boga i bliźniego, dz. cyt., s. 81-82; Księga Kaptańska, wstęp, tłum. z oryginału, komentarz oprac. A. Tronina, dz. cyt., s. 287; Księga Kaptańska, wstęp, tłum. z oryginału, komentarz, ekskursy oprac. S. Łach, dz. cyt., s. 241; S. Hałas, Biblijne stownictwo mitości i mitosierdzia na zderzeniu kultur, dz. cyt., s. 253-254. 
mógł być pułapką) czy przekonania, które blokują dostęp do niego (kontakt z krwią lub zwłokami powodował nieczystość rytualną). W sytuacji zagrożenia zdrowia lub życia każdy z nas chciałby, żeby znalazł się przy nim bliźni, który przyjdzie z pomocą, niezależnie od tego, kim jest i skąd pochodzi.

Postawa Samarytanina pokazuje też, na czym polega prawdziwa miłość bliźniego. Najpierw trzeba zobaczyć (ópó $\omega$ ) drugiego człowieka, nie mieć wzroku skierowanego tylko na siebie i swoje sprawy. Następnie trzeba wzruszyć się głęboko ( $\sigma \pi \lambda \alpha \gamma \chi v i \zeta o \mu \alpha \imath)$ sytuacją dostrzeżonego człowieka. Czasownik $\sigma \pi \lambda \alpha \gamma \chi v i ́ \zeta o \mu \alpha ı$ pochodzi od rzeczownika $\sigma \pi \lambda \alpha ́ \gamma \chi v \alpha$ („wnętrzności, serce; serdeczność, czułość, miłość, litość”) i oznacza „czuć litość, wzruszać się, współczuć”31, i to do tego stopnia, że człowiekowi poruszają się wnętrzności. Czasownik ten w Nowym Testamencie odnosi się tylko do Jezusa oraz do postaci z przypowieści, które symbolizują Boga (Mt 18, 27; Łk 15, 20). Samarytanin odzwierciedla więc postawę Boga i Jezusa. To wewnętrzne przeżycie musi w końcu przełożyć się na konkretne działanie. Samarytanin podchodzi do leżącego człowieka, opatruje jego rany, zalewając je oliwą i winem, zawozi do gospody na swoim bydlęciu i pielęgnuje go, a kiedy musi odjechać, powierza rannego gospodarzowi i daje dwa denary, zapewniając, że przy powrocie odda mu, jeśli ten wyda więcej. Nie szczędzi więc swego czasu, pieniędzy i starań, okazując w ten sposób pobitemu człowieko-

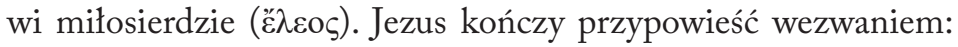
„Idź, i ty czyń podobnie!” (Łk 10, 37), bo zachowanie Samarytanina jest przykładem doskonałej miłości bliźniego, obrazem samego Jezusa ${ }^{32}$.

31 R. Popowski, Wielki stownik grecko-polski Nowego Testamentu, dz. cyt., s. 561-562.

32 Por. Ewangelia wedtug św. Eukasza, cz. 1, dz. cyt., s. 563-565; Kompendium der Gleichnisse Jesu, Hrsg. R. von Zimmermann, Gütersloh 2007, 
Pan Jezus rozszerza miłość bliźniego także na nieprzyjaciół, wzywając do nieodpłacania im złem za zło, ale do modlitwy za nich, błogosławienia im i wyświadczania im dobra na wzór Boga (Mt 5, 38-48; Łk 6, 27-36). Daje też nowe przykazanie miłości wzajemnej, w której już nie my, ale On sam ma być miarą miłości: „Przykazanie nowe daję wam, abyście się wzajemnie miłowali, tak jak Ja was umiłowałem; żebyście i wy tak się miłowali wzajemnie" ( J 13, 34; por. 15, 12.17). A Jezus umiłował nas do końca, oddając za nas życie, co jest wyrazem największej miłości ( J 13, 1; 15, 13; Rz 5, 6-10). Do takiej miłości jesteśmy wszyscy wezwani. „Po tym poznaliśmy miłość, że On oddał za nas życie swoje. My także winniśmy oddać życie za braci” $(1 \mathrm{~J} 3,16)$.

\subsection{MIŁość Do ŚWIATA}

Nie mamy w Piśmie Świętym tekstów, które wzywałyby do miłowania świata. Przeciwnie, spotykamy przestrogi, aby tego nie

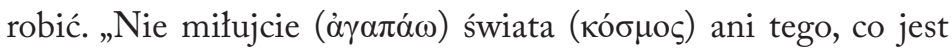
na świecie. Jeśli ktoś miłuje świat, nie ma w nim miłości Ojca. Wszystko bowiem, co jest na świecie, a więc: pożądliwość ciała, pożądliwość oczu i pycha tego życia, pochodzi nie od Ojca, lecz od świata" (1 J 2, 15-16). Świat przedstawiany jest, zwłaszcza w pismach św. Jana i św. Pawła, jako opanowany przez zło, wrogi wobec Boga i Jego wyznawców. Świat nienawidzi ( $\mu 1 \sigma \varepsilon ́ \omega)$ Jezusa i Jego uczniów (J 7, 7; 15, 18-19; 1 J 3, 13). Dlatego nie możemy brać wzoru $z$ tego świata, ale mamy odnawiać się umysłem i rozpoznawać, jaka jest wola Boża, co jest miłe Bogu (Rz 12, 2; Jk 1, 27). Jeśli korzystamy ze świata, to tak jakby ( $\dot{\omega})$ z niego nie korzystając (1 Kor 7, 31). Powinniśmy zwyciężać świat za pomocą wiary w Boga

s. 538-555; Przypowieści Jezusa, wprowadzenie i objaśnienie A. Paciorek, Częstochowa 2013, s. 269-282. 
i w Jezusa, Jego Syna (1 J 5, 4-5; 4, 4; Rz 8, 37), który zwyciężył świat (J 16, 33).

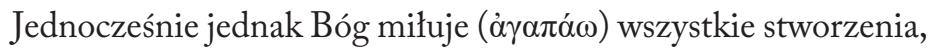
niczym się nie brzydzi, co uczynił, bo gdyby miał coś w nienawiści $(\beta \delta \varepsilon \lambda v ́ \sigma \sigma \omega)$, nie uczyniłby tego (Mdr 11, 24). Stworzony świat mówi o Bogu, swoim Stwórcy, o Jego potędze i wspaniałości (Mdr 13, 1-5; Rz 1, 20). Bóg miłuje zwłaszcza świat ludzi mimo ich grzechu i zepsucia, albo może jeszcze bardziej z powodu ich słabości, i posłał do niego Syna, aby świat zbawił, a nie potępił ( J 3, 16). Grzech człowieka rzucił cień na całe stworzenie. Odkupienie człowieka, odnowienie w nim obrazu Bożego ( $\mathrm{Rz}$ 9, 29; Ef 4, 24; Kol 3, 10) pociągnie za sobą wyzwolenie całego stworzenia z niewoli zepsucia i marności oraz udział w chwale Bożej. Stworzenie oczekuje tego $\mathrm{z}$ upragnieniem, jęcząc $\mathrm{w}$ bólach rodzenia ( $\mathrm{Rz}$ 8, 19-22). Historia stworzenia zdąża do chwalebnego końca, do odnowy wszystkiego, do nowego nieba i nowej ziemi, w których zamieszkają sprawiedliwość, pokój i życie (2 P 3, 13; Ap 21, 1). Jezus Chrystus został posłany do świata, aby dokonać jego odkupienia i odnowienia. Uczynił to z miłości do Ojca i do świata (J 17, 18; $\mathrm{Rz}$ 5, 6-11). My jesteśmy również posłani do świata, aby nieść mu Ewangelię zbawienia, uwolnienie od zła i udział w życiu w chwale (Flp 2, 15) 33. Mamy miłować świat i współpracować w dziele odkupienia, aby całe stworzenie odzyskało splendor zgodnie z pierwotnym zamysłem Boga.

Jak widać, miłość do Boga i do bliźniego w analizowanych tekstach (Pwt 6, 5; Kpł 19, 18) nie ogranicza się do uczucia, ale angażuje intensywnie całego człowieka, wszystkie jego władze: rozum, wolę, sumienie, działanie, uczucia. Polega ona na spełnianiu przykazań, co jest wyrazem zawierzenia Bogu, przylgnięcia do Niego, a także dowartościowania drugiego człowieka, troski,

33 Por. F. Rienecker, G. Maier, Leksykon biblijny, dz. cyt., s. 235. 
aby go chronić przed złem i nieść mu dobro. Miłość do świata jest motywowana tym, że jest on dziełem Boga przeznaczonym do chwały pomimo skażenia, jakiemu uległ na skutek grzechów ludzi. Jest on dla człowieka siedliskiem życia i źródłem pożywienia. Trzeba brać za niego odpowiedzialność, strzec przed zniszczeniem, kierować w stronę pełnego rozwoju.

\section{Relacje zawarte w praktykach pobożnych}

Relacje z Bogiem, z drugimi i ze światem realizują się najpełniej w miłości, która powinna jednak znaleźć konkretne formy wyrazu. Są nimi m.in. modlitwa, jałmużna i post, trzy praktyki znane i zalecane w Starym Testamencie, przejęte również przez Jezusa i Jego uczniów. Praktyki te są podejmowane w Kościele, zwłaszcza w okresie wielkiego postu, aby przygotować się na obchód misterium paschalnego Chrystusa, w którym człowiek odnawia siebie i swoje relacje.

Pan Jezus wypowiedział się na temat tych trzech praktyk (Mt 6, 1-18) $)^{34}$ w Kazaniu na Górze. Zwraca uwagę, aby tych uczynków pobożnych nie wykonywać dla pokazania się ludziom, bo inaczej ominie nas nagroda Ojca w niebie (Mt 6, 1). Oznacza to, że uczynki te zostaną w ten sposób zafałszowane, stracą swoją wartość, nie przyniosą spodziewanych owoców. Uczynki te powinny pozostać w ukryciu ('่v $\tau \tilde{\varphi} \kappa \rho v \pi \tau \tilde{\omega})$ (Mt 6, 4.6.18), aby nie zostały skażone przez dodatkowe intencje, sprzeczne z zasadniczymi celami podejmowanych działań. Nie można postępować w tych punktach jak obłudnicy (i்oкрıт́s) (Mt 6, 2. 5. 16).

34 Fragment tego tekstu (Mt 6, 1-6. 16-18) stanowi Ewangelię czytaną w Środę Popielcową. 


\section{I. MODLITWA}

Modlitwy ( $\pi \rho \circ \sigma \varepsilon v ́ \chi 0 \mu \alpha \imath)$ nie można podejmować publicznie w synagogach i na rogach ulic tylko po to, żeby się ludziom pokazać. Sensem modlitwy jest nasza ścisła relacja z Bogiem, dlatego powinna mieć ona bardzo osobisty, intymny charakter. W tym celu dobrze jest zamknąc się w swojej izdebce i pozostać sam na sam z Bogiem. Wtedy modlitwa osiągnie swój cel, bo będzie prowadziła do ściślejszego zjednoczenia z Bogiem. Jej wartość nie polega też na wielomówstwie, ale powinna koncentrować się na tym, co myśli i czego pragnie Bóg (Mt 6, 5-8). Wskazane cechy Jezus zawarł w modlitwie Ojcze nasz, której nauczył uczniów. Mają oni widzieć w Bogu Ojca i zabiegać o świętość Jego imienia, obecność Jego Królestwa, wypełnianie Jego woli. Z potrzeb człowieka modlitwa ta wymienia codzienny chleb - jego podstawowe pożywienie, przebaczenie grzechów, pomoc w próbach i pokusach oraz wyzwolenie od zła. Jak widzimy, są to sprawy najpotrzebniejsze, w przeważającej mierze dotyczące wymiaru duchowego człowieka, bo nawet chleb może oznaczać również Eucharystię. Znamienne jest położenie akcentu na przebaczenie grzechów ze strony Boga uwarunkowane naszym przebaczeniem wobec tych, którzy zaciągnęli jakąś winę względem nas. Przebaczenie uzdrawia nasze relacje $z$ Bogiem i z drugimi. Modlitwa Pańska uczy ufności i szacunku względem Boga, pogłębia naszą relację z Nim w aspekcie jednostkowym i wspólnotowym, ponieważ używa się w niej konsekwentnie pierwszej osoby liczby mnogiej (Mt 6, 9-15) ${ }^{35}$.

Łukasz dołącza do swojej wersji modlitwy Ojcze nasz (Łk 11, 2-4) przypowieść o natrętnym przyjacielu, który o północy prosi

35 Por. Ewangelia wedtug św. Mateusza, cz. 1, Rozdziaty 1-13, wstęp, tłum. z oryginału, komentarz oprac. A. Paciorek, Częstochowa 2005, s. 260-280 (Nowy Komentarz Biblijny. Nowy Testament, 1.1). 
o pożyczenie mu trzech chlebów (Łk 11, 5-8). Opowiadanie to pokazuje, że natręctwem można przełamać niechęć drugiego i uzyskać od niego to, czego potrzebujemy. Podobną wymowę ma przypowieść o wdowie, która zadręczała sędziego, dopóki nie wziął jej w obronę (Łk 18, 1-8). Kolejne wersety (Łk 11, 9-13; por. Mt 7, 7-11) zachęcają do takiej postawy względem Boga: „Proście, a będzie wam dane”, motywując ją dodatkowo przykładem ojca, który na pewno spełni prośbę syna o chleb, rybę czy jajko, a nie poda mu kamienia, węża czy skorpiona. Tym bardziej Bóg da proszącym Go to, co dobre, a przede wszystkim swojego Ducha. Dar Ducha umożliwia głęboką relację z Bogiem. Trzeba jednak zachować pokorę jak celnik w przeciwieństwie do faryzeusza, który się wywyższał i pogardzał innymi (Łk 18, 9-14) ${ }^{36}$.

Jezus wiele mówił na temat modlitwy, a równocześnie był mężem modlitwy w nieustannym dialogu ze swoim Ojcem. Aramejski termin „Abba” (Mk 14, 36; Rz 8, 15; Ga 4, 6), którego używał i który przejęli Jego uczniowie, niesie w sobie poufałość połączoną z szacunkiem. Jezus potrafił całą noc spędzić na modlitwie do Boga (Łk 6, 12; Mt 14, 23; Mk 6, 46-47; J 6, 47-48). Była to modlitwa uwielbienia, dziękczynienia, prośby, nacechowana wielką ufnością i śmiałością. Wyrażała Jego szczególną relację z Bogiem. Takiej modlitwy Jezus uczył swoich uczniów, chciał ich włączyć w swoją modlitwę i w swoją relację z Ojcem. W ich przypadku dochodziły jeszcze aspekt przebłagania, prośba o przebaczenie grzechów. Pismo Święte jest wielką księgą modlitwy. Podaje teksty modlitw i przykłady ludzi modlących się. Wzywa do modlitwy w każdym czasie (Łk 21,36), do modlitwy nieustannej (1 Tes 5, 17; por. 1, 2; 2, 13; Dz 12, 5). Modlitwa jest bowiem niezbędna, jeśli chcemy żyć w stałej relacji z Bogiem. Gdy ofiarowujemy ją za innych, łączy nas

36 Por. Ewangelia wedtug św. Eukasza, cz. 1, dz. cyt., s. 576-594; Ewangelia wedtug św. Mateusza, cz. 1, dz. cyt., s. 308-312. 
ona także z bliźnimi, buduje głęboką relację z nimi. Relacje między ludźmi oparte na modlitwie są bodaj najgłębsze i najtrwalsze. Nade wszystko modlitwa buduje naszą relację z Bogiem. Słowo słuchane i wypowiadane jest najlepszym narzędziem tej relacji. Słowo to musi być jednak potwierdzone w życiu. Nie wystarczy mówić: „Panie, Panie”, ale trzeba wypełniać Jego słowo. Gdy ktoś dopuszcza się nieprawości, jego relacja z Bogiem jest pozorna. Chrystus powie o takich, że ich nie zna i żeby od Niego odeszli (Mt 7, 21-23; Łk 6, 46; 13, 25-27).

\subsection{JAŁMUŻNA}

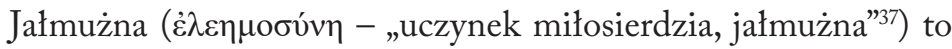
konkretna, bezinteresowna pomoc materialna dla drugiego człowieka podyktowana miłosierdziem. Powinna być ofiarowana dyskretnie, aby lewa ręka nie wiedziała, co czyni prawa. Nie można trąbić o niej w synagogach i na ulicach, aby być chwalonym przez ludzi. Byłoby to działanie obłudne, mające na celu siebie, a nie drugiego człowieka, który potrzebuje pomocy. Darczyńca powinien pozostać w cieniu. Nagrodą dla niego jest dobro drugiego człowieka i lepsza relacja z nim, a ostatecznie nagroda od Ojca w niebie, którą jest dobra i trwała relacja z Nim i ze zbawionymi. Jałmużna jest wyrazem konkretnej miłości bliźniego i powinna skutkować pogłębieniem relacji z nim. Dlatego dając ją, nie możemy skupiać się tylko na jej aspekcie zewnętrznym i liczyć, co, ile i komu daliśmy, lecz trzeba pytać, czy ten dar zewnętrzny rzeczywiście przybliżył nas do drugiego człowieka. Sam dar zewnętrzny, w postaci jakiegoś datku, ale może to być również dobre słowo, ofiarowany czas itp., jest jednak ważny, bo bez niego nasza miłość bliźniego

37 R. Popowski, Wielki stownik grecko-polski Nowego Testamentu, dz. cyt., s. 190. 
byłaby jedynie słowna, pozbawiona treści (Mt 6, 2-4). Święty Jan przestrzegał przed taką postawą: „Dzieci, nie miłujmy słowem i językiem, ale czynem i prawdą" (1 J 3, 18; por. Jk 2, 14-19) ${ }^{38}$.

W przypowieści o bogaczu i Łazarzu (Łk 16, 19-31) Jezus ukazuje przepaść obojętności między bogaczem bawiącym się świetnie dzień w dzień a biednym czekającym u jego bramy na odpadki z jego stołu; przepaść ta utrwala się na wieczność. Nie ma między tymi postaciami żadnej relacji. Jezus zachęcał do bezinteresownego daru dla drugiego na wzór Boga: dawać każdemu, kto prosi, nie odwracać się od tego, kto chce pożyczyć, nie oczekiwać zwrotu (Mt 5, 42; Łk 6, 30. 35); zaprosić na ucztę biednych i chorych, którzy nie będą mogli się zrewanżować (Łk 14, 12-14). Taki dar rodzi nowe relacje między ludźmi, umacnia już istniejące.

\subsection{POST}

Post ( $\eta \sigma \tau \varepsilon v ́ \omega)$ również nie powinien być na pokaz, podejmowany z posępną miną i ponurym wyglądem. Raczej trzeba zadbać o swój zewnętrzny wygląd, umyć sobie twarz i namaścić głowę, aby ludzie nawet nie zauważyli naszego postu (Mt 6, 16-18). Zwykle uwidaczniano go przez znaki zewnętrzne: zakładano wór pokutny, rezygnowano $z$ codziennych obmyć, posypywano głowę popiołem lub ziemią (1 Krl 21, 27; Ne 9, 1). Różne były przyczyny podejmowania postu: po śmierci bliskiej osoby (1 Sm 31, 13; $2 \mathrm{Sm} 1,12$ ), przed ważną decyzją, której wynik zależał jedynie od Boga (2 Sm 12,16. 21-23; Est 4, 3.16), w okresie pokuty (1 Sm 7, 6; $1 \mathrm{Krl} 21,27$; Ezd 10, 6; Ne 9, 1; Jon 3, 7-8), dla większego zjednoczenia z Bogiem (Wj 34, 28; Pwt 9, 9. 18), dla zintensyfikowania modlitwy błagalnej (Dn 10, 3. 12). Izraelici pościli w Dniu Przebłagania (Kpł 16, 29-31; Dz 29, 9). Po wygnaniu babilońskim podejmowali

38 Por. Ewangelia wedtug śrw. Mateusza, cz. 1, dz. cyt., s. 255-260. 
post w cztery dni związane $\mathrm{z}$ oblężeniem i zajęciem Jerozolimy (Jr 41, 1-2; 52, 4. 6-7. 12-13; Za 7, 3. 5). Zewnętrzny post zaczął być traktowany jako dobry uczynek prowadzący do zbawienia (Iz 58, 5-6; Za 7, 5-6). W czasach Jezusa faryzeusze pościli w poniedziałki i czwartki (Łk 18, 12; Mt 9, 14; Mk 2, 18; Łk 5, 33). Jezus, podobnie jak wcześniej Mojżesz (Wj 34, 28) i Eliasz (1 Krl 19, 8), pościł przez czterdzieści dni, aby przygotować się do podjęcia misji (Mt 4, 2; Łk 4, 2). Przywiązywał jednak do postu mniejszą wagę, choć widział jego potrzebę obok modlitwy dla uleczenia epileptyka (Mt 17, 21; Mk 9, 29). Jego uczniowie pościli mniej niż uczniowie Jana Chrzciciela i faryzeusze (Mt 9, 14; Mk 2, 18; Łk 5, 33), ale po zesłaniu Ducha Świętego post był podejmowany przez Pawła (Dz 9, 9; 2 Kor 6, 5), przez Pawła i Barnabę przy ustanowieniu starszych $(\mathrm{Dz} 14,23)$ oraz przez wspólnotę antiocheńską przy wysyłaniu Pawła i Barnaby na misję (Dz 13, 2-3) ${ }^{39}$.

Powstrzymanie się od pokarmu na jakiś czas czy ograniczenie go, niezależnie z jakich motywów, oznacza kontrolowane korzystanie z dóbr świata. Człowiek nie ulega zachłanności, lecz potrafi w sposób umiarkowany podchodzić do świata. Jest to postawa pożądana i powinna być rozszerzona poza kwestie żywieniowe na inne dziedziny, jak transport czy energetyka. Taka postawa oznacza mądrość i szacunek wobec świata otrzymanego w darze od Boga, z którego mamy prawo korzystać, ale jednocześnie powinniśmy dbać o niego i strzec go, by nie uległ degradacji i nie przestał być domem i ogrodem dla człowieka i innych istot żywych.

Wymaganie Jezusa, aby modlitwę, jałmużnę i post podejmować w ukryciu, nie wyklucza możliwości wykonywania tych praktyk publicznie. Jezus chciał, żeby inni widzieli nasze dobre czyny i chwalili Ojca w niebie (Mt5, 16), żeby Jego uczniowie gromadzili

39 Por. F. Rienecker, G. Maier, Leksykon biblijny, dz. cyt., s. 644-645; Ewangelia wedtug św. Mateusza, cz. 1, dz. cyt., s. 280-282. 
się razem (Mt 18, 19-20). Wyakcentował przesadnie intymny charakter tych czynów pobożnych, aby ostrzec przed wypaczeniem ich właściwych celów i skutków. Są nimi pogłębione relacje z Bogiem, drugim człowiekiem i ze światem. Jeśli te praktyki nie osiągają tego celu, są w pewnej mierze bezużyteczne. Same w sobie są jednak bardzo potrzebne, bo konkretyzują miłość do Boga, bliźniego i świata.

\section{Podsumowanie}

Pismo Święte mówi o człowieku jako jednostce, podkreśla jego osobową godność, wolność i odpowiedzialność, a jednocześnie rozpatruje go zawsze w środowisku i we wspólnocie, w których żyje, działa i się spełnia. Aspekt wspólnotowy jest w najstarszych księgach biblijnych bardzo mocny, natomiast z biegiem czasu stawał się nieco słabszy ${ }^{40}$, chociaż jest wciąż o wiele bardziej wyrazisty niż obecnie w naszej kulturze, w której dominuje indywidualizm posunięty niekiedy bardzo daleko ze szkodą dla człowieka i wspólnoty.

Autorzy biblijni ukazują człowieka w splocie relacji z Bogiem, drugim człowiekiem i ze światem. Relacje te są zarysowane w sposób fundamentalny w Rdz 1 - 3, gdzie można znaleźć opowiadania o stworzeniu świata i człowieka oraz o upadku pierwszych ludzi. Zamysłem Stwórcy wszystkiego był harmonijny kosmos, w którym każde stworzenie ma swoje miejsce i żyje w zgodnych relacjach z innymi bytami. Niestety grzech pierwszych ludzi spowodował zakłócenie tych relacji. Bóg stara się je uzdrowić w całej dalszej historii, zwłaszcza przez dzieło odkupienia dokonane przez Jego Syna Jezusa Chrystusa.

40 Por. A. Gelin, Pismo święte o cztowieku, tłum. z jęz. fr. D. Szumska, Paris 1971, s. 55-67 (Znaki Czasu, 18). 
Najważniejsza dla człowieka jest jego relacja z Bogiem. Został on stworzony na obraz i podobieństwo Boże jako zwieńczenie całego dzieła stworzenia, jest koroną wszystkich bytów widzialnych. Nikt ze stworzeń poza człowiekiem nie jest nazwany obrazem Bożym. Dzięki temu człowiek pozostaje w szczególnej relacji z Bogiem. Prowadzi z Nim dialog i jest Jego reprezentantem w świecie. Bóg obdarzył go wielkim zaufaniem, powierzył mu cały świat. Człowiek powinien więc odnosić się do Niego z wiarą, wdzięcznością i szacunkiem, przestrzegać ustanowionych przez Niego praw i odpowiedzialnie podejmować zlecone mu zadanie, z którego zda rachunek Panu - Stwórcy, Prawodawcy i Sędziemu. Człowiek jednak okazał nieposłuszeństwo i po grzechu zaczął się Boga lękać i ukrywać się przed Nim.

Człowiek potrzebuje relacji z drugimi, nie może żyć samotnie. Dlatego został stworzony jako mężczyzna i kobieta, których łączy szczególna relacja, bogata i płodna. Oboje są równi co do godności i mają razem podejmować otrzymane zadania prokreacji i opanowywania świata. Są dla siebie partnerami i uzupełniają się, mogą sobie wzajemnie pomagać. Grzech naruszył tę ścisłą wspólnotę, widać zrzucanie odpowiedzialności i tendencję do panowania ze strony mężczyzny, który wykorzystuje pragnienie kobiety skierowane ku niemu. Wypełnianie otrzymanych zadań macierzyństwa i pracy przychodzi im teraz z trudem i bólem.

Człowiek pozostaje także w relacji do świata. Stoi wyżej nad zwierzętami, wśród których nie znajduje odpowiedniej pomocy. Określa ich pozycję i panuje nad nimi, aby mu nie zagrażały. Ma zaludniać świat i czynić sobie ziemię poddaną. Nie oznacza to jednak, że może maltretować zwierzęta i niszczyć świat. Ma uprawiać ziemię, troszczyć się o nią i jej strzec jako mądry, zapobiegliwy gospodarz. Grzech naruszył również tę relację. Świat okazuje się wrogi, rodzi osty i ciernie zamiast płodów nadających się do spożycia, stanowi zagrożenie. Człowiek 
natomiast eksploatuje świat nie do końca rozsądnie, niszcząc go i szkodząc sobie.

Najlepszą i najpełniejszą formą relacji do Boga, człowieka i świata jest miłość. Pismo Święte apeluje o nią, zwłaszcza w odniesieniu do Boga i bliźniego. W odniesieniu do Boga i człowieka została ona ujęta w formie przykazań, które są najważniejsze, stanowią streszczenie wszystkich norm moralnych. Miłość do Boga powinna objąć całego człowieka, jego serce, duszę i siłę, i wyrazić się w zaufaniu, szacunku i posłuszeństwie. Również miłość do bliźniego jest postawą całego człowieka i polega na traktowaniu go tak, jak traktujemy siebie, jak traktuje go Jezus. Miłość ta wyraża się w akceptacji drugiego człowieka, wrażliwości na jego potrzeby, trosce o jego dobro. Miłość do świata nie wybrzmiewa równie mocno, autorzy biblijni wskazują raczej na jego złą stronę i zalecają dystans wobec niego. Jednak Bóg miłuje świat mimo jego skażenia i pragnie mu przywrócić pierwotny splendor. Odkupienie dokonane przez Jezusa ma stać się również udziałem świata, który tego oczekuje. Podobna powinna być nasza postawa wobec świata.

Konkretnym wyrazem miłości do Boga jest modlitwa. Podejmując ją mądrze i wytrwale, możemy trwać w szczerym dialogu z Bogiem, który stanowi istotę relacji. Jałmużna jest bezinteresownym darem dla drugiego człowieka, aby zaradzić jego potrzebom rozpoznanym dzięki empatii. Na tym polega autentyczna miłość do bliźniego. Post to powstrzymanie się od pokarmu na jakiś czas, co jest niełatwe, bo potrzebujemy stale pokarmu dla utrzymania zdrowia i życia. Opanowanie w jedzeniu i piciu oznacza mądre korzystanie $z$ dóbr świata. Rozciągnięcie takiej postawy na inne dobra obecne w świecie można nazwać miłością do niego, bo nie wykorzystujemy go ponad to, czego naprawdę potrzebujemy. Taka miłość może powstrzymać szybko postępującą dzisiaj degradację świata, za który jesteśmy odpowiedzialni. 
Człowiek jest osobą, sam decyduje o sobie, ale do pełni potrzebuje dobrych relacji z Bogiem, z drugimi i ze światem. One zapewniają poprawną relację do siebie samego, która jest również ważna. Biblia ukazuje, jak te relacje zostały pomyślane przez Stwórcę, jak uległy skażeniu przez grzechy i jak Bóg w Chrystusie stara się je naprawić i doprowadzić do harmonii. Jest to cenna lekcja, która pozwala nam lepiej rozumieć naszą sytuację i włączyć się w stwórcze i odkupieńcze dzieło Boga, aby mieć radość i życie w obfitości we wspólnocie $\mathrm{z}$ innymi.

\section{Wybrana bibliografia}

1. Barclay W., Ważniejsze stowa Nowego Testamentu, tłum. P. Kuciński, Warszawa 1988.

2. Biblia Hebraica Stuttgartensia, ed. K. Elliger, W. Rudolph, editio quinta emendata, Stuttgart 1997.

3. Biblia Święta, to jest Księgi Starego i Nowego Przymierza z żydowskiego i greckiego jezzyka na polski pilnie $i$ wiernie przettumaczone [Biblia gdańska], Gdańsk 1632.

4. Biblia w przektadzie księdza Jakuba Wujka z 1599 r., transkrypcja typu „B” oryginalnego tekstu z XVI wieku i wstępy J. Frankowski, Warszawa 1999 (Prymasowska Seria Biblijna, 10).

5. Bovati P., Księga Powtórzonego Prawa (1-11), red. nauk. T. M. Dąbek, tłum. L. Furman, Kraków 1998 (Rozumieć Stary Testament. Komentarze Duchowe).

6. Encyklopedia biblijna, red. P. J. Achtemeier, tłum. G. Berny i in., Warszawa 1999 (Prymasowska Seria Biblijna, 9).

7. Ewangelia wedtug św. Eukasza, cz. 1, Rozdziaty 1-11; cz. 2, Rozdziaty 12-24, wstęp, tłum. z oryginału, komentarz oprac. F. Mickiewicz, Częstochowa 2011-2012 (Nowy Komentarz Biblijny. Nowy Testament, 3.1-2). 
8. Ewangelia wedtug św. Marka, wstęp, tłum. z oryginału, komentarz oprac. H. Langkammer, Poznań-Warszawa 1977 (Pismo Święte Nowego Testamentu w 12 Tomach, 3.2).

9. Ewangelia wedtug św. Mateusza, cz. 1, Rozdziaty 1-13; cz. 2, Rodziaty 14-28, wstęp, tłum. z oryginału, komentarz oprac. A. Paciorek, Częstochowa 2005-2008 (Nowy Komentarz Biblijny. Nowy Testament, 1.1-2).

10. Gelin A., Pismo święte o człowieku, tłum. z jęz. fr. D. Szumska, Paris 1971 (Znaki Czasu, 18).

11. Hałas S., Biblijne stownictwo mitości i mitosierdzia na zderzeniu kultur. Określenia hebrajskie i ich odpowiedniki greckie, Kraków 2011 (Studia - Uniwersytet Papieski Jana Pawła II w Krakowie. Wydział Teologiczny, 18).

12. Jasnos R., Teologia prawa w Deuteronomium, Kraków 2001 (Studia Pedagogiczne).

13. Koehler L., Baumgartner W., Stamm J. J., Wielki stownik hebrajsko-polski i aramejsko-polski Starego Testamentu, t. 1-2, red. nauk. wyd. pol. P. Dec, tłum. K. Madaj i in., Warszawa 2008 (Prymasowska Seria Biblijna, 30).

14. Kompendium der Gleichnisse Jesu, Hrsg. R. von Zimmermann, Gütersloh 2007.

15. Księga Kapłańska, wstęp, tłum. z oryginału, komentarz oprac. A. Tronina, Częstochowa 2006 (Nowy Komentarz Biblijny. Stary Testament, 3).

16. Księga Kaptańska, wstęp, tłum. z oryginału, komentarz, ekskursy oprac. S. Łach, Poznań-Warszawa 1970 (Pismo Święte Starego Testamentu, 2.1).

17. Ksiega Powtórzonego Prawa, wstęp, tłum. z oryginału, komentarz, ekskursy oprac. S. Łach, Poznań-Warszawa 1971 (Pismo Święte Starego Testamentu, 2.3). 
18. Ksiega Rodzaju, cz. 1, Rozdziaty 1-11, wstęp, tłum. z oryginału, komentarz oprac. J. Lemański, Częstochowa 2013 (Nowy Komentarz Biblijny. Stary Testament, 1.1).

19. Lohfink G., 50 listów o wierze. Jak dzisiaj być chrześcijaninem, tłum. E. Pieciul-Karmińska, Kielce 2019.

20. Lust J. et al., A Greek-English Lexicon of the Septuagint, Vol. 1-2, Stuttgart 1992-1996.

21. Novum Testamentum graece, Hrsg. B. Aland et al., 28. revidierte Auflage, Stuttgart 2012.

22. Pismo Święte Starego i Nowego Testamentu w przektadzie zjęzyków oryginalnych [Biblia Tysiąclecia], oprac. zespół biblistów polskich z inicjatywy benedyktynów tynieckich, Poznań 2002.

23. Popowski R., Wielki stownik grecko-polski Nowego Testamentu. Wydanie z petnq lokalizacja greckich haset, kluczem polsko-greckim oraz indeksem form czasownikowych, wyd. 2, Warszawa 1995 (Prymasowska Seria Biblijna,3).

24. Przypowieści Jezusa, wprowadzenie i objaśnienie A. Paciorek, Częstochowa 2013.

25. Rienecker F., Maier G., Leksykon biblijny, tłum. D. Irmińska, J. Kruczyńska, Warszawa 2001 (Prymasowska Seria Biblijna,18).

26. Stownik grecko-polski, red. Z. Abramowiczówna, t. 1-4, Warszawa 1958-1965.

27. Wojciechowski M., Pochodzenie świata, cztowieka, zta. Odpowiedź Biblii, Częstochowa 2005.

28. Wronka S., Dwa czy trzy przykazania mitości (Mt 22, 34-40 i par.)?, „Zeszyty Naukowe Stowarzyszenia Biblistów Polskich” 8 (2011) nr 8, s. 375-393.

29. Wronka S., Największe przykazania mitości Boga i bliźniego, w: Na Troje stowo, Panie..., red. D. Czaicki, Kraków 2018, s. 73-100.

30. Wronka S., Transliteracja i transkrypcja alfabetu hebrajskiego, „Ruch Biblijny i Liturgiczny” 57 (2004) nr 1, s. 45-58. 